\title{
フェライトアスファルト混合物の振動性状
}

\section{VIBRATING PROPERTIES OF FERRITE ASPHALT MIXTURES}

間山正一*

By Masakazu MAYAMA

\begin{abstract}
This paper describes vibrating properties of ferrite-asphalt composite materials which were obtained through mixing ferrite byproducts with asphalt. The vibrating properties were measured by the fundamental bending vibration for specimen hung at the modal points. Following conclusions were obtained. 1) The higher the temperature, the larger was the logarithmic decrement, the smaller was the resonance frequencies and the smaller was the dynamic modulus. 2) The quality of asphalt had small effects on material properties comparing with the effects of temperature. 3) Logarithmic decrement had quantitative relationships with dynamic modulus.
\end{abstract}

Keywords : ferrite asphalt mixtures, vibrating properties, logarithmic decrement, dynamic modulus

\section{1. 概 説}

著者はフェライト混合物の応用研究1) 1 つである制 振材料としての振動特性を研究してきた ${ }^{2), 3)}$.この振動 特性に関する研究は道路や空港の分野で特に問題となっ ている交通振動や騒音等を初めとする環境問題 ${ }^{4}$ への対 処と同時に舗装材料の振動性状の解明や舗装体の振動測 定 $^{51}$, 理論解析 ${ }^{6)}$ やそのコンピューター・プログラムを 開発して行った研究7)等を進展させることによって, 舗 装体の振動メカニズムを解明することを目的としたもの である。

同時に, 現在, 土木・建築・船舶等の分野でその技術 開発に凌ぎを削っているいわゆる免振構造物, 免振工法 の材料の 1 つとして研究対象となっているものである.

本研究は, 一連の制振材料 ${ }^{2), 3)}$ 之同様に, そのための 基礎的データとすべく, 自由減衰振動方式によって副産 物フェライトとアスファルトの混合からなる混合物（以 下, フェライトアスファルト混合物と称す) の振動性状, すなわち, 対数減衰率, 共振時弾性率 (動的弾性率), および振動性状相互の関係を明らかにすることを主たる 目的亡する.

* 正会員 工博 北海道工業大学教授 工学部土木工学科 ( $\overline{\mathbf{T} 006}$ 札㨪市西区手稲前田 419-2)
また, この種の混合物の材料性状は温度, アスファル 卜量, アスファルトの性質等に依存することが知られて いるが，本稿においては紙面の都合で振動性状と温度お よびアスファルトの性質の関係についてのみ報告するも のとする.

なお, 本研究で用いた副産物フェライトは天然に産出 する磁鉄鉱と同性状のもので安定性が高く1), また, ア スファルトとの混合で得られるフェライトアスファルト 混合物は舗装, 制振壁, 床材料, 基礎材料, ラミネート 材料等の制振材料として用いられると同時に, 磁気標識

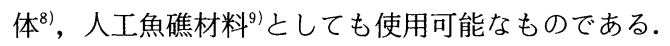

\section{2. 実験材料と試験方法}

\section{（1）材料}

本研究ではアスファルトの物理的性質が振動性状に与 える影響を検討するため, その物理性状が大きく異なる 表一1に示した 3 種類のアスファルトを選択し, 副産物 フェライト粉末 ${ }^{1) ~ 3)}$ と混合して供試体を作製した. 前述 したように，アスファルト量については別途テーマを構 成するほど興味ある対象であるが，ここではマーシャル

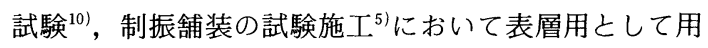
いたフェライトアスファルト混合物のアスファルト量を 参考に, $7 \%$ のものに限定した. 
表一1アスファルトの物理性状

\begin{tabular}{|c|c|c|c|c|}
\hline 名 称 & 比 重 & 针人度 ${ }^{1)}$ & $\left.\operatorname{TREB}^{(}{ }^{\circ} \mathrm{C}\right)$ & P.1. ${ }^{2)}$ \\
\hline $\mathrm{A}$ & 1.020 & 69 & 55.5 & +1.70 \\
$\mathrm{~B}$ & 1.020 & 92 & 46.5 & -0.60 \\
$\mathrm{C}$ & 1.020 & 215 & 36.7 & -1.30 \\
\hline
\end{tabular}

1) $100 \mathrm{~g}, 5 \mathrm{sec}, 25^{\circ} \mathrm{C}$

2) 針入度指数

供試体の作製方法は，従来の舗装用アスファルト混合 物之同様であり，供試体寸法は曲げ試験に用いた寸法 ${ }^{11}$ と同じ $3 \times 3 \times 25 \mathrm{~cm}$ である角型棒状供試体を 1 種類に つき, 3 本用いた.

なお，表一1に示したアスファルトの呼称に従って， 副産物フェライトとの混合によって得られるフェライト アスファルト混合物をそれぞれ A 混合物, B 混合物,

$\mathrm{C}$ 混合物と称した。また，これらの平均密度は等しく， $3.522\left(\mathrm{~g} / \mathrm{cm}^{3}\right)$ であった。

\section{（2）振 動試験}

本研究に用いた振動試験法は 2 本吊りの方法による自 由減衰振動法である.その詳細についてはすでに報告し た2),3)のでここでは割愛する.

なお, 本試験によって材料の対数減衰率 $\delta$, 共振周波 数 $f_{0}$, 共振時弾性率 (動的弾性率) $E_{f}$ が求められるが, $f_{0}$ は供試体寸法に依存することから，また， $E_{f}$ と一定 の関係で表現されることから ${ }^{2), 3)}$, 本稿においては $E_{f}$

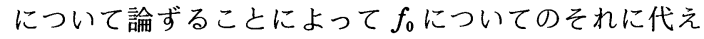
たい.

\section{3. 実験結果と考察}

\section{（1）振動性状と温度の関係}

図一1 は A 混合物, B 混合物, C 混合物の $\delta$ 之温度 の関係を示す.

アスファルトの性質を問わず，どの混合物も温度の上 昇とともに $\delta$ が増大するが，その変化の割合は見掛け 上，低温側ほざ大きい， $\delta$ は減衰の速さを示す量である ことから，ここで揭げたフェライトアスファルト混合物 は高温になるに従って外力の吸収性能が大きくなること がわかるが，この主な理由はこの種のアスファルト混合 物に共通してみられる粘性項が大きくなるためと同時 に，高温になるほど副産物フェライトとアスファルトの 刺激に対するミスマッチングが大きくなるためと考えら れる.

図一2 は各種混合物の $E_{f}$ と温度の関係である. B 混 合物の場合を例にとって説明すると, $+40^{\circ} \mathrm{C}$ で約 3.7 $\times 10^{3}\left(\mathrm{~kg} / \mathrm{cm}^{2}\right)$ の $E_{f}$ は, $+20^{\circ} \mathrm{C}$ で約 12.2 倍の約 4.5 $\times 10^{4}\left(\mathrm{~kg} / \mathrm{cm}^{2}\right)$ になり, $0^{\circ} \mathrm{C}$ で約 $1.3 \times 10^{5}\left(\mathrm{~kg} / \mathrm{cm}^{2}\right)$ の $E_{f}$ は $-20^{\circ} \mathrm{C}$ では約 1.5 倍の約 $2.0 \times 10^{5}\left(\mathrm{~kg} / \mathrm{cm}^{2}\right)$ の $E_{f}$ になっており, 同一温度変化に対する $E_{f}$ の変化

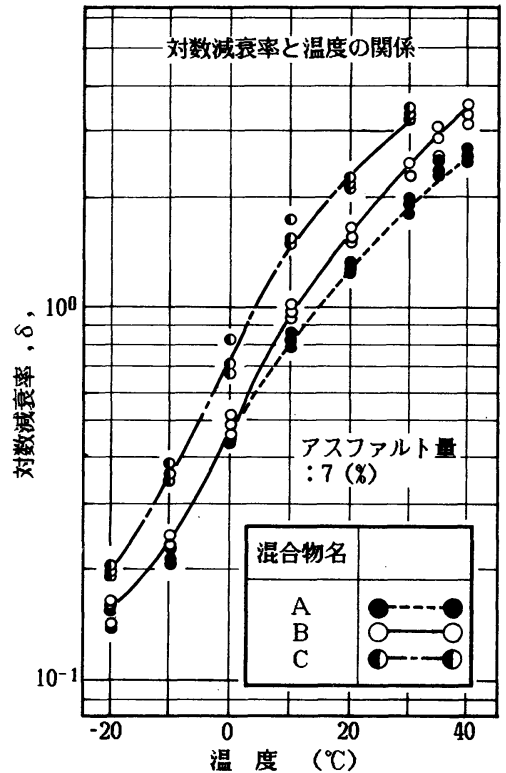

図一1各種のフェライトァスファルト混合物の対数減衰率と温 度の関係

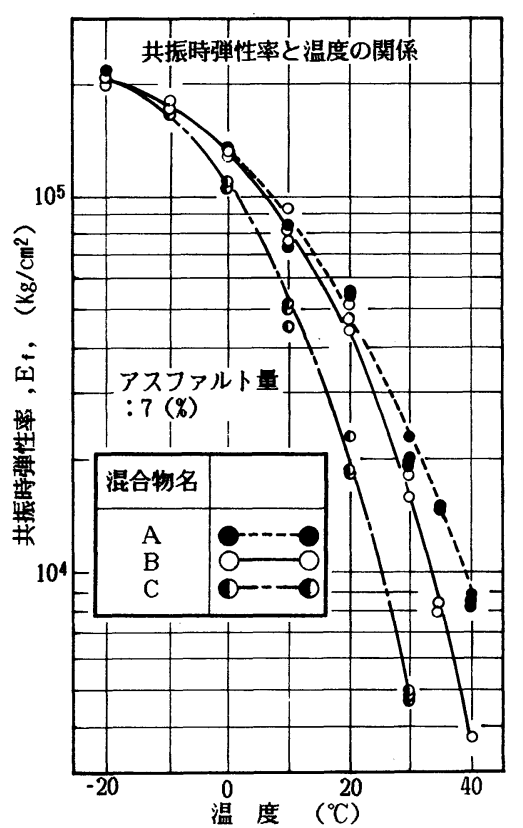

図一2 各種のフェライトアスファルト混合物の共振時弾性率と 温度の関係

の割合は高温側の方が大きい，なお， $E_{f}$ の差をみた場 合には, $+40^{\circ} \mathrm{C}$ と $+20^{\circ} \mathrm{C}$ の $E_{f}$ の差は約 $4.1 \times 10^{4}$ $\left(\mathrm{kg} / \mathrm{cm}^{2}\right)$ であるのに対して $0^{\circ} \mathrm{C}$ と $-20^{\circ} \mathrm{C}$ のそれは $7.0 \times 10^{4}\left(\mathrm{~kg} / \mathrm{cm}^{2}\right)$ となっており，低温側における差の 方が大きい点にも留意する必要がある. 


\section{（2）振動性状とアスファルトの性状の関係}

先に揭げた図一1 から P.I. の小さい（低軟化点, 高 針入度）アスファルトを結合材とする C 混合物はどの 温度領域においても $\delta$ が大きく, A 混合物と B 混合物 の $\delta$ は $0{ }^{\circ} \mathrm{C} よ り$ 高温になるに従ってその差が大きくな る. 同様に, 図一2から $E_{f}$ は低温側では同じであるが, 温度が高くなるに従って差が生ずる．わかりやすくする ため, 一例として， $E_{f}$ と軟化点の関係を図一-3に示す. 温度の上昇とともに $E_{f}$ が減少するが，その割合は C 混 合物, B 混合物, A 混合物の順に大きく, 特に, C 混 合物の $E_{f}$ の減少割合は著しい.フェライトアスファル 卜混合物は研磨材に用いられるほど剛性が高く, かつ, その温度依存性をほとんど無視できる副産物フェライト 亡, 剛性が小さく, かつ, それが温度や時間に依存する アスファルトから構成される. したがって, 刺激へのレ スポンスが異なり，その差すなわち，ミスマッチングが 粘性とともに振動を吸収する要因の 1 つと考えられる. 同時に, 低温側ではアスファルトのスティフネスが副産 物フェライトのそれに近づくため, 両者の混合からなる 混合物としてのレスポンスとして表われる $\delta$ あるいは $E_{f}$ にアスファルトの性状の差は出ないが, 高温になる に従って両者の剛性の差が大きくなるため, 結局, アス ファルトの性状の差が $\delta$ や $E_{f}$ として表われるものと考 えられる.

\section{（3）対数減衰率と共振時弾性率の関係}

$\delta$ と $E_{f}$ の関係は学問的に興味あるばかりでなく, そ の工学的応用を考える場合にも重要なデー夕となる. 本 研究で用いた 3 種類の混合物について $\delta$ と $E_{f}$ の関係を 両対数グラフにプロットした結果，図一4に示すように， $E_{f}$ の増加とともに $\delta$ が減少するなめらかな曲線が得ら れた. 高温側に相当する左上では両対数グラフ上の見掛 けの勾配は比較的フラットであるが，右下になるにつれ て勾配が急になる，すなわち，同一温度変化幅で考える と, 見掛け上, 高温側では $E_{f}$ の変化の割合に対して $\delta$ の変化の割合が小さく, 逆に, 低温側では $\delta$ の変化の 割合に対して $E_{f}$ の変化の割合が小さい. 先に, 図一1 および図一2において， $\delta$ の温度による変化の割合は低 温側ほど大きく, $E_{f}$ のそれは高温側ほど大きいことを 指摘したが, 図一4 はこの両図をまとめたものであるこ とから上記の傾向については肯首されよう.

粘弾性的挙動をするこの種の混合物は転移領域をはさ んで, 高温領域においてはより粘性的挙動を示し, 低温 領域においてはより弾性的挙動を示すことはよく知られ ている.この場合, 両端の温度領域に近づくに従って粘 性あるいは弾性の上限值に近づいていくため, その絶対 値は大きくなるが, 增加の割合は小さくなるものと考え られる.この材料性状を念頭におくことによって, 図一

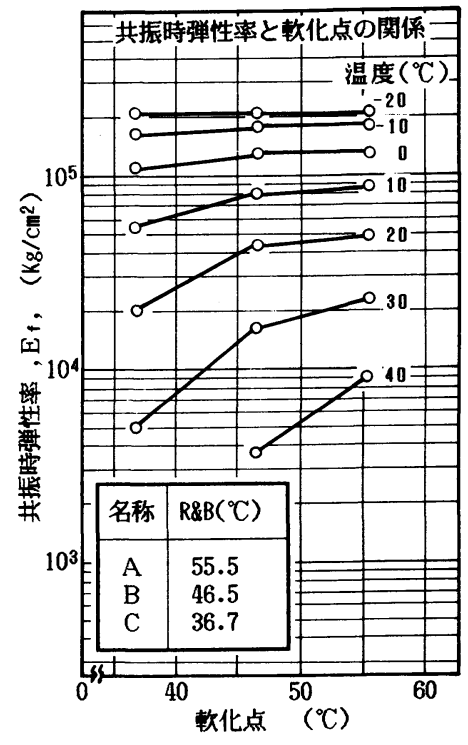

図一3 各種のフェライトアスファルト混合物の共振時弾性率と 軟化点の関係

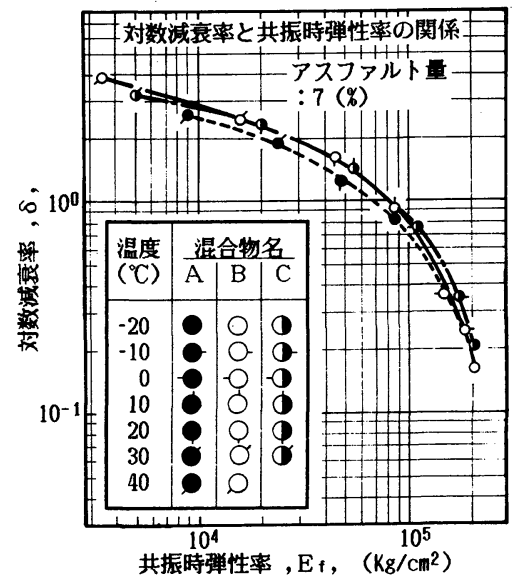

図一4 各種のフェライトアスファルト混合物の対数減衰率と共 振時弾性率の関係

4 の振動性状が理解される，たとえば，低温側では混合 物の弾性率の上限に近づいていくため, 動的弾性率であ る横軸の $E_{f}$ の増加率はしだいに小さくなって, 右下に 急な $\delta$ vs. $E_{f}$ 曲線になるものと推定される. 逆に, 高 温側では材料が粘性的になり, 弾性項である $E_{f}$ の減少 率に比較して, 粘性項として表現される縦軸の $\delta$ が上 限値にしだいに近づいていくため, その増加率が小さく なることから結局, フラットな曲線になるものと推定さ れる.

次に，混合物の種類ごとに図一4をみると，A 混合物 (低針入度, 高軟化点, 高 P.I. ) は $\delta$ vs. $E_{f}$ 曲線が他 のそれらに比較して, 最も内側にあることから同一 $E_{f}$ 
に対する $\delta$ が最も小さく，また，同一 $\delta$ に対する $E_{f} も$ 小さいが，おおまかに把えた場合，各混合物の $\delta \mathrm{vs.}$ $E_{f}$ 曲線の一般形状の差は比較的小さいといえよう.ア スファルトの種類が 3 種類と限定されているが, 本研究 の範囲内ではある狭い幅の中で任意の $\delta$ と $E_{f}$ が対応づ けられるといえよう.

\section{4. 結 論}

多様な用途をもつフェライトアスファルト混合物を開 発し, 自由減衰振動試験を行った結果, 明らかにされた 事項を列記する.

（1）温度の上昇とともに混合物の対数減衰率が大き くなり, 共振時弾性率が小さくなることを明らかにした。

(2) P.I. の小さいアスファルトほど同一温度にお ける $\delta$ が大きくなり, 共振周波数および共振時弾性率 が小さくなるが, その影響は従来のアスファルト混合物 に比較して，比較的少ないことを示した。

（3）両対数目盛りでみた場合, 対数減衰率と共振時 弾性率の振動性状相互の関係がなめらかな曲線で表現さ れ, 低温領域では共振時弾性率の増減率よりも対数減衰 率の増減率の方が大きく, 高温領域ではその逆の性状に なることを見出した。

（4）これは低温領域では弾性率の上限値に近づくの でその増加率が鈍化するのに対して, 高温領域では粘性 が支配的になってその増加率が小さくなるためであるこ とを考察した。

\section{5. 後 記}

多様な用途をもつ副産物フェライト混合物の 1 つであ るフェライトアスファルト混合物の振動性状について論 じた.フェライトアスファルト混合物の振動性状に与え るアスファルト量の影響, 材料性状と構造物としての挙 動との関係に関する実験および理論解析等の興味ある データを保有しているが, 機会が与えられたならばご批
判を頂戴したい.

最後に, 本研究を行うに際して, セントラルコンサル タント (株) 谷藤正三相談役, 日本電気環境エンジニア リング (株) 过 俊郎社長, 日本電気 (株) 資源環境技 術研究所の菅野 出所長に多大のご指導を願った。ここ に厚く謝意を表したい.

\section{参 考 文 献}

1）間山正一・山内文雄：副産物フェライトの土木工学への 応用, 土木学会誌, 1987-5, Vol.72, pp. 35 40, 1987.

2）間山正一：コーテッドフェライトコンクリートの振動性 状, 土木学会論文集, 第 384 号 $/ \mathrm{V}-7$, pp. 93 101, 1987.

3）間山正一：フェライトエポキシ混合物の振動性状と力学 的性状, 土木学会論文集, 第 385 号 / VI-7, pp. 59 68, 1987.

4) 土木学会学会誌編集委員会 : 土木と環境, 土木学会誌, Vol.71, 1986-9 月号, pp.2 53, 1986.

5）間山正一ほか：舗装体の振動測定法, 土木学会北海道支 部論文報告集, 第 43 号, pp. 565 570， 1987.

6) たとえば, Lysmer, J. and Waas, G. : Shear waves in plane infinite structures, ASCE, EM 1, pp. $85 \sim 105$, 1972.

7） SAP, SDM，FLUSH 等が広く利用されているが，使 いやすい例として, 花里利一・鵜飼忠三：走行荷重によ り生ずる地盤振動の FEM 解析, 土質工学会論文報告集, Vol. 23, No. 1, 1983.

8）間山正一ほか：副産物フェライトを利用した磁気標識体, 土木学会論文集, 第 379 号 $/ \mathrm{VI}-6$, pp. 78 82, 1987.

9）間山正一・山内文雄: 副産物フェライトを利用した藻礁, 水産土木, 第 23 巻, 第 1 号, pp. 7 12, 1986.

10）間山正一・辻 俊郎：フェライト混合物の力学的性状に 関する基礎的研究, 土木学会第 38 回年次学術講演会講演 概要集, pp. 467, 1983.

11）間山正一ほか：制振舗装材料の曲げ破壊性状，第 15 回日 本道路会議一般論文集, pp. 299 300, 1983.

(1987.7.30 - 受付) 